\title{
Isolation and Characterization of a Non-Helical Strain of Spiroplasma citri
}

\author{
By R. TOWNSEND, P. G. MARKHAM, KITTY A. PLASKITT \\ AND M. J. DANIELS \\ John Innes Institute, Colney Lane, Norwich NR4 7 UH
}

(Received 4 November 1976)

SUMMAR Y

A non-helical strain of Spiroplasma citri from little-leaf diseased oranges was subcultured over 40 times in different media without producing helical cells. It was non-motile and produced colonies of a characteristic morphology on soft agar plates. Serology, DNA hybridization and toxin production confirmed that it was a strain of $S$. citri but its membrane protein pattern after polyacrylamide gel electrophoresis differed from those of other $S$. citri strains in that one band was absent. The organism caused symptoms in plants identical to those produced by a pathogenic helical strain of $S$. citri.

\section{INTRODUCTION}

Spiroplasmas differ from other Mollicutes in shape and motility. All those isolated are typically helical during at least part of their growth phase and show rotary or 'screw'-like motility as well as flexing movements. The helical shape is apparently maintained without the assistance of a rigid cell wall or axial filaments (Cole et al., 1973).

Spiroplasma citri was isolated and characterized by Saglio et al. (1973) and is the leafhopper-transmitted agent of little-leaf disease of citrus (Markham et al., 1974). We have isolated a pathogenic strain of $S$. citri, which lacks the characteristic helical morphology, from diseased citrus material.

\section{METHODS}

Isolation and culture. A non-helical spiroplasma and six normal strains of S. citri were isolated from 'lop-sided' fruits of little-leaf diseased sweet orange trees by the method of Daniels et al. (1973). Isolates were subcultured twice in complete sorbitol medium (SMC; Saglio et al., 1973) without arginine and tryptone, before $0.1 \mathrm{ml}$ samples were plated on SMC solidified with I \% (w/v) agar (Oxoid no. I). After incubation for 7 days at $32{ }^{\circ} \mathrm{C}$, colonies showing unusual morphology were picked off into SMC medium. One of these isolates was cloned three times and designated ASP-I. All cultures were maintained in SMC at $32{ }^{\circ} \mathrm{C}$. Characterized strains of $S$. citri $\mathrm{R} 8-\mathrm{A} 2$ (type strain) and CI 89 were kindly supplied by Dr P. Saglio, and the pathogenic strain SP-A was isolated in this laboratory (Daniels et al., 1973).

Media and incubation conditions. The colony and cell morphologies of strains SP-A and ASP-I were compared under different conditions. Plates of SMC solidified with $0.75 \%$ and $\mathrm{I} \%(\mathrm{w} / \mathrm{v})$ agar were spread with $0.1 \mathrm{ml}$ of diluted spiroplasma culture and incubated at $32{ }^{\circ} \mathrm{C}$ for 7 days in air or in $\mathrm{N}_{2} / \mathrm{CO}_{2}(95: 5, \mathrm{v} / \mathrm{v})$. Cultures in $\mathrm{SMC}$ were incubated at 25,28 , 
32 and $37^{\circ} \mathrm{C}$. The osmolarity of SMC was altered by varying the concentration of sorbitol up to maximum of $20 \%(\mathrm{w} / \mathrm{v})$. Sera tested included $20 \%(\mathrm{v} / \mathrm{v})$ horse serum (Gibco-Biocult, Paisely, Renfrewshire), $20 \%$ (v/v) horse serum no. 3 (Wellcome Reagents), $20 \%(\mathrm{v} / \mathrm{v})$ donor horse serum (Sera Lab., Crawley, Sussex), Io \% (v/v) foetal calf serum (Gibco-Biocult), $10 \%(\mathrm{v} / \mathrm{v})$ fresh chicken serum and $20 \%(\mathrm{v} / \mathrm{v})$ horse serum from which globulins had been removed by ammonium sulphate precipitation. All sera were heated at $60{ }^{\circ} \mathrm{C}$ for $30 \mathrm{~min}$ before use and were tested against both strains in SMC and on SMC with $0.75 \%$ agar.

Light and electron microscopy. Spiroplasma morphology was examined by dark field optics, and colonies, unstained or stained with Dienes' stain (Scriba, 1968), were examined with a stereo dissecting microscope. Cultures in the exponential phase of growth were fixed by adding an equal volume of $7 \%$ (w/v) glutaraldehyde in SMC (Cole, Tully \& Popkin, I974) and negatively stained with saturated uranyl acetate for electron microscopy. Examinations for the presence of virus particles in strain ASP-I were performed by Dr R. M. Cole, National Institutes of Health, Bethesda, Maryland, U.S.A. Sections of diseased plant tissue were prepared and examined as described by Markham et al. (1974).

Motility. Molten $0.5 \%$ agar (Oxoid no. 2) at $40{ }^{\circ} \mathrm{C}$ was added to an equal volume of exponentially growing culture. Movement of the organisms through the agar was observed by dark field microscopy.

$\mathrm{Gel}$ electrophoresis. Spiroplasmas were harvested by centrifugation at $20000 \mathrm{~g}$ for $30 \mathrm{~min}$ at $4{ }^{\circ} \mathrm{C}$ from $100 \mathrm{ml}$ cultures in SMC with $10 \%(\mathrm{v} / \mathrm{v})$ horse serum, and membranes were prepared by a procedure similar to that described by Razin et al. (1973). After solubilization in a mixture of $2 \%(\mathrm{w} / \mathrm{v})$ sodium dodecyl sulphate (SDS), $2 \%(\mathrm{v} / \mathrm{v}) 2$-mercaptoethanol and $20 \%(\mathrm{w} / \mathrm{v})$ sucrose, and heating for $3 \mathrm{~min}$ at $100{ }^{\circ} \mathrm{C}$, samples of these preparations were run in $7.5 \%(\mathrm{w} / \mathrm{v})$ polyacrylamide-SDS gels (Hull, 197I) which were then stained and photographed (Daniels \& Meddins, I973).

Growth. Strains SP-A and ASP-I were grown in $5 \mathrm{ml}$ portions of SMC supplemented with $\left[2-{ }^{14} \mathrm{C}\right]$ thymidine $\left(57 \mathrm{mCi} \mathrm{mmol}^{-1}\right.$, about $\left.0.1 \mu \mathrm{Ci} \mathrm{ml}^{-1}\right)$. Samples $(0 . \mathrm{I} \mathrm{ml})$ were removed at various times after inoculation. Growth was measured by colony-forming units (c.f.u.) and by the quantity of $\left[{ }^{14} \mathrm{C}\right]$ thymidine incorporated (Daniels, I969).

Serology. Antiserum to $S$. citri SP-A was produced as described previously (Markham et al., 1974). Spiroplasmas were compared by metabolic inhibition tests (Taylor-Robinson et al., 1966) and growth inhibition tests (Clyde, 1964). Mycoplasma mycoides subsp. capri and Acholeplasma laidlawii were included as negative controls.

DNA hybridization. DNA was prepared from $(500 \mathrm{ml})$ cultures of spiroplasmas and $M$. mycoides by the method of Marmur (196I). Radioactive DNA from strain SP-A was obtained after growth in $500 \mathrm{ml}$ SMC supplemented with $\left[\right.$ methyl $\left.{ }^{3} \mathrm{H}\right]$ thymidine $(46 \mathrm{Ci}$ $\mathrm{mmol}^{-1}$, about $\mathrm{I} \mu \mathrm{Ci} \mathrm{m}^{-1}$ ). Homologies were assessed by hybridizing $2 \mu \mathrm{g}$ of denatured, radioactively-labelled DNA from strain SP-A with $50 \mu \mathrm{g}$ of denatured, unlabelled DNA fixed on filters in the presence of $50 \%(\mathrm{v} / \mathrm{v})$ formamide (Saglio et al., 1974). After $36 \mathrm{~h}$ incubation at $37{ }^{\circ} \mathrm{C}$, the filters were washed and dried and the fixed radioactivity was determined by liquid scintillation counting.

Toxin production. Spiroplasma citri toxin was partially purified from the cell-free supernatant fluids of SP-A and ASP-I cultures and then tested on pieces cut from broad bean leaves (unpublished).

Pathogenicity tests. Leafhoppers were reared, injected and maintained as reported previously (Markham et al., 1974). (i) 120 Euscelis plebejus leafhoppers were injected with strain SP-A and 120 with strain ASP-I. Insects were caged on white clover for 3 weeks, and the survivors were then transferred in groups of 6 or 12 to 12 broad bean seedlings for 


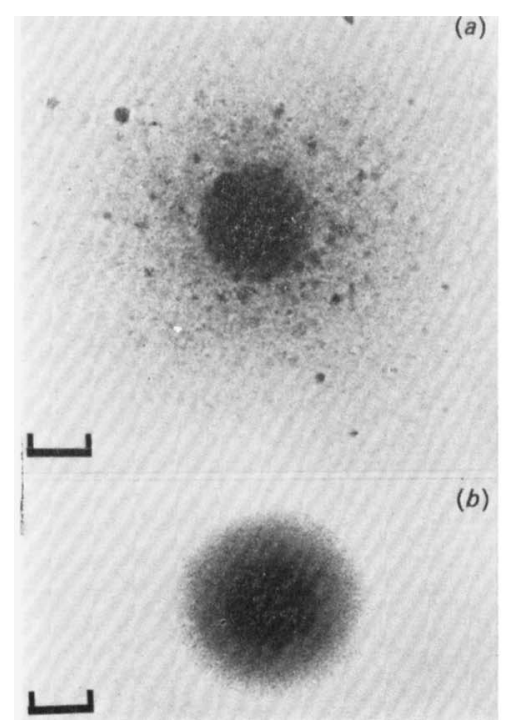

Fig. I

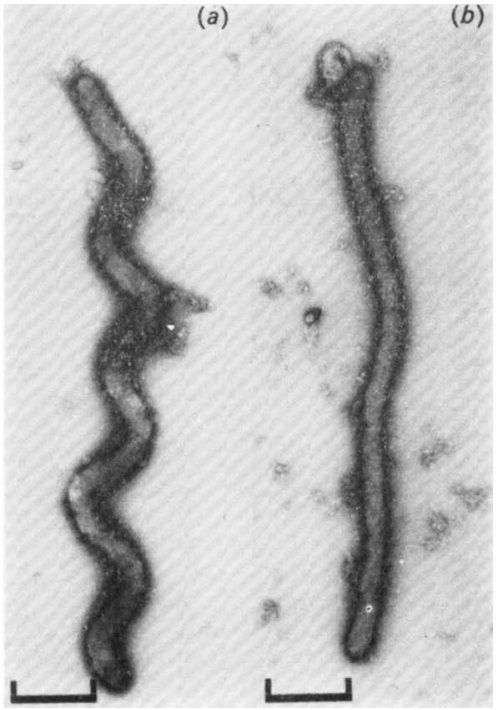

Fig. 2

Fig. I. Stained colonies of $S$. citri strains (a) SP-A and (b) ASP-I on SMC medium solidified with $0.75 \%$ agar. Bar markers represent $0.01 \mathrm{~mm}$.

Fig. 2. Negatively stained organisms from exponential phase cultures of $S$. citri strains (a) SP-A and (b) ASP-I. Bar markers represent $0.5 \mu \mathrm{m}$.

2 weeks. (ii) 300 Euscelidius variegatus insects were injected with strain ASP-I, caged on rye-grass for 3 weeks and then transferred in groups of 8 to 21 broad bean plants.

\section{RESULTS}

Colony morphology. Six isolates produced colonies which were poorly defined 'fried eggs' less than $0 . \mathrm{I} \mathrm{mm}$ diam., slightly brown, granular and surrounded by tiny satellite colonies, typical of the SP-A strain of $S$. citri (Fig. I $a$ ). However, about I $\%$ of the colonies from one batch of diseased oranges were atypical well-defined 'fried eggs' about $0.05 \mathrm{~mm}$ diam., transparent, smooth and without satellite colonies (Fig. I $b$ ). This morphology was maintained throughout subculture and cloning and was typical of strain ASP-I. The differences in colony morphology between strains SP-A and ASP-I were most apparent on plates containing $0.75 \%$ agar. No reversion of the ASP-I colony type to the SP-A colony form was observed in $\mathrm{N}_{2} / \mathrm{CO}_{2}$ or on any of the media used. Both organisms produced the largest colonies on agar containing $10 \%(\mathrm{v} / \mathrm{v})$ foetal calf serum or $10 \%(\mathrm{v} / \mathrm{v})$ chicken serum and the smallest colonies with $20 \%(\mathrm{v} / \mathrm{v})$ globulin-free horse serum.

Cell morphology. Exponential phase cultures of strain ASP-I contained flexuous filaments, many of which were branched and tangled into large clumps. No helical cells were observed during more than 40 subcultures. Fixed, negatively stained preparations showed that the organisms had similar dimensions to SP-A spiroplasmas (about 3 to $8 \mu \mathrm{m} \times 0.2 \mu \mathrm{m}$ ) (Fig. $2 a$ ) but were not helical (Fig. 2 b). Three viruses, SV-CI, SV-C2 and SV-C3 (Cole et al., I974), which are normally associated with helical forms of $S$. citri, including strain SP-A, were identified in strain ASP-I. Complete extracellular particles of SV-CI and SV-C 3 and incomplete intracellular particles of $\mathrm{SV}-\mathrm{C}_{2}$ or $\mathrm{SV}-\mathrm{C}_{3}$ were present in cultures examined by 


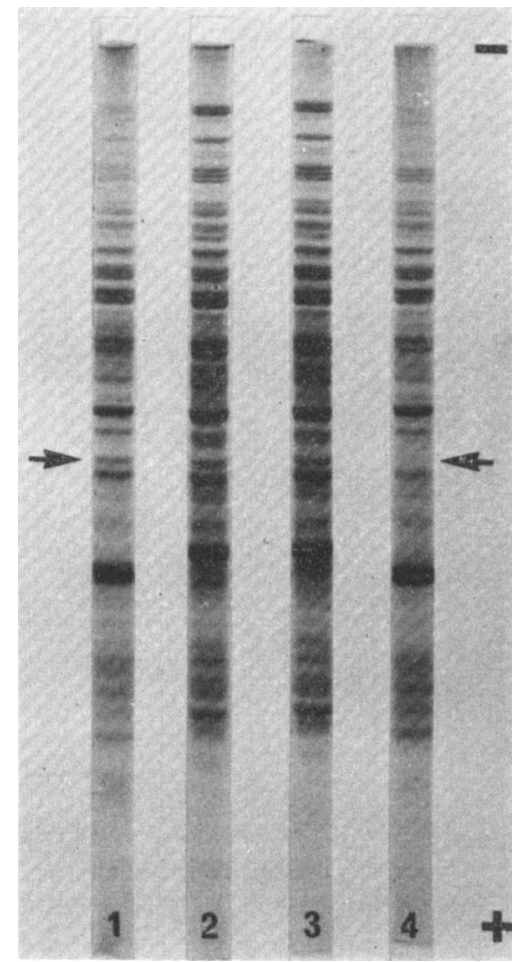

Fig. 3. Electrophoretic patterns of partially purified $S$. citri membrane proteins: I, SP-A; 2, R8-A2; $3, \mathrm{CI} 89 ; 4$, ASP-1. The position of the pattern variation is marked by the arrows.

Dr R. M. Cole. Subsequently we observed occasional complete extracellular particles of SV-C2.

Both strains grew best at $32{ }^{\circ} \mathrm{C}$ and progressively less well at 30,28 and $25{ }^{\circ} \mathrm{C}$. After $48 \mathrm{~h}$ incubation at $32{ }^{\circ} \mathrm{C}$ both strains produced sufficient acid to turn the phenol red indicator yellow and the $\mathrm{pH}$ of the medium ultimately fell below 5. Both strains grew well in media containing 0 to $10 \%(\mathrm{w} / \mathrm{v})$ sorbitol but poorly with $20 \%(\mathrm{w} / \mathrm{v})$ sorbitol, though varying the osmolarity of the medium had no effect on the morphology of strain ASP-I. None of the sera tested caused strain ASP-I to become helical, but medium containing $20 \%(\mathrm{v} / \mathrm{v})$ of certain batches of horse serum no. 3 (Wellcome Reagents) did cause strain SP-A to produce distorted cells which often lacked a definite spiral. The same serum caused both strains to clump. Neither strain grew well in media containing $20 \%(\mathrm{v} / \mathrm{v})$ globulin-free horse serum.

Motility. In soft agar, strain SP-A showed characteristic rotational motion and flexing of the organisms. Filaments of strain ASP-I produced erratic twitching movements only.

Gel electrophoresis. The membrane protein patterns of strains SP-A, R8-A2, CI89 and ASP-I were identical, qualitatively, except that one band was absent in gels of ASP-I (Fig. 3).

Growth curves. Cultures of strains SP-A and ASP-I grew at similar rates when measured by $\left[{ }^{14} \mathrm{C}\right]$ thymidine incorporation (Fig. 4), but ASP-I apparently had a longer lag phase when measured by c.f.u. (Fig. 5). Both organisms produced peak titres of more than $\mathrm{I} \times \mathrm{IO}^{9}$ c.f.u. $\mathrm{ml}^{-1}$.

Serological reactions. Antiserum to $S$. citri SP-A was equally inhibitory to $S$. citri SP-A and ASP-I but not to $M$. mycoides or A. laidlawii (Table I). 


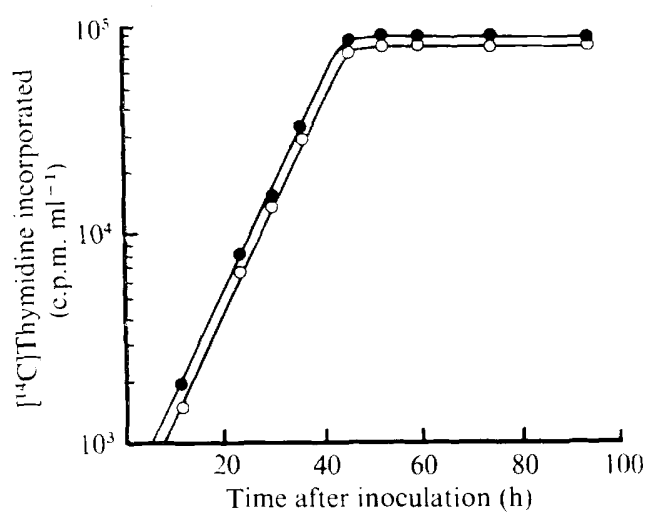

Fig. 4

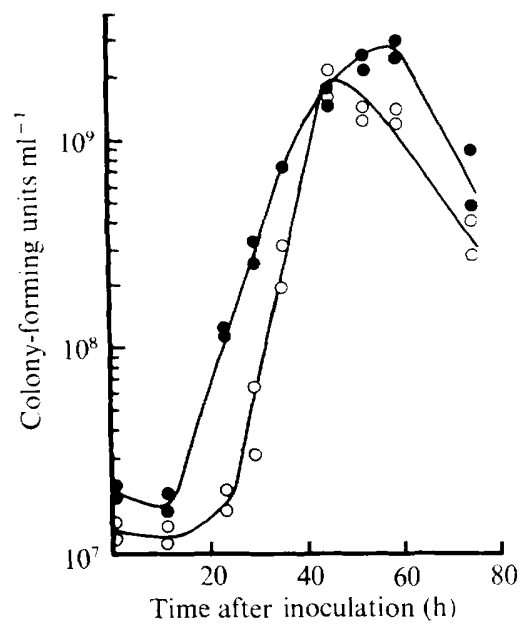

Fig. 5

Fig. 4. Growth curves of $S$. citri strains.SP-A (๑) and ASP-I $(O)$ in SMC medium at $32{ }^{\circ} \mathrm{C}$, as measured by incorporation of $\left[2-{ }^{14} \mathrm{C}\right]$ thymidine $\left(0 \cdot \mathrm{I} \mu \mathrm{Ci} \mathrm{ml}^{-1}\right)$.

Fig. 5. Growth curves of S. citri strains SP-A (O) and ASP-I $(O)$ in SMC medium at $32{ }^{\circ} \mathrm{C}$, as measured by colony-forming units.

Table I. Inhibitory activity of antiserum to $S$. citri $\mathrm{SP}-\mathrm{A}$ on spiroplasmas and mycoplasmas

Metabolic inhibition titres are expressed as the highest dilution of antiserum which permitted acid production by cultures in SMC medium after 4 days incubation at $32{ }^{\circ} \mathrm{C}$ for spiroplasmas and after 3 days incubation at $37^{\circ} \mathrm{C}$ for mycoplasmas.

Growth inhibition results are expressed as the diameter of the zone of growth inhibition surrounding a $6 \mathrm{~mm}$ diam. filter paper disc impregnated with $20 \mu \mathrm{l}$ antiserum after 7 days incubation at $32{ }^{\circ} \mathrm{C}$ for spiroplasmas and after 4 days incubation at $37^{\circ} \mathrm{C}$ for mycoplasmas.

$\begin{array}{lrc}\text { Strain } & \begin{array}{c}\text { Metabolic } \\ \text { inhibition } \\ \text { titre }\end{array} & \begin{array}{c}\text { Growth } \\ \text { inhibition } \\ \text { zone (mm) }\end{array} \\ \text { S. citri } \text { SP-A } & 1024 & 5 \cdot 0 \\ \text { S. citri ASP-I } & 1024 & 4.5 \\ \text { M. mycoides (capri) } & 8 & - \\ \text { A. laidlawii } & 8 & -\end{array}$

Table 2. DNA-DNA hybridization among strains of $S$. citri and M. mycoides (capri)

Radioactive DNA from strain SP-A was incubated with non-radioactive DNA, from various strains, immobilized on filters. After $36 \mathrm{~h}$, the amount of radioactivity fixed on the filters was measured. The degree of hybridization is expressed as a percentage relative to the hybridization with DNA from strain SP-A itself $(=100)$.

DNA on filter

Filter without DNA

S. citri SP-A

S. citri $\mathrm{R} 8-\mathrm{A} 2$

S. citri $\mathrm{Cl} 89$

S. citri ASP-I

M. mycoides (capri)
Fixed radioactivity Percentage (c.p.m.) hybridization

$\begin{array}{rr}472 & - \\ 3966 & 100 \\ 4302 & 108 \\ 397 I & 100 \\ 3919 & 99 \\ 460 & 0\end{array}$




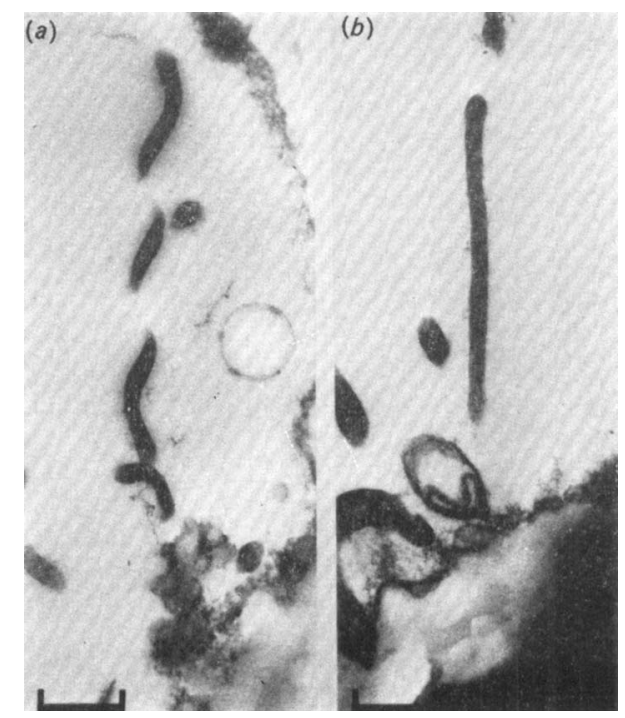

Fig. 6. Thick sections (I 50 to $200 \mathrm{~nm}$ ) of the phloem cells in broad beans infected with $S$. citri strains (a) SP-A and (b) ASP-I. Bar markers represent $0.5 \mu \mathrm{m}$.

DNA homology. DNA-DNA hybridization showed complete homology between the spiroplasmas but not with $M$. mycoides (Table 2).

Toxin production. Both strains produced a toxin which blackened pieces of broad bean leaves.

Pathogenicity. Three of six bean plants were infected with little-leaf disease by Euscelis plebejus insects injected with strain SP-A. Spiroplasmas were cultured from surviving insects and infected plants. Insects injected with strain ASP-I infected two of six plants. Euscelidius variegatus infected with strain ASP-I infected five of $2 \mathrm{I}$ bean plants. Only non-helical organisms were isolated from insects and plants. Bean plants infected with strain ASP-I showed the same progression of symptoms as those infected by strain SP-A. Sections cut from SP-A-infected plants showed typical spiroplasmas in the phloem cells (Fig. $6 a$ ) but similar cells of ASP-I-infected plants contained straight filaments (Fig. $6 b$ ), many of which were branched.

\section{DISCUSSION}

Serology tests, DNA homology studies, electrophoretic analysis, the production of toxin and pathogenicity tests showed that ASP-I was a strain of $S$. citri and not a contaminating filamentous mycoplasma.

Temporary changes in the morphology of $S$. citri have been noted before: ageing cultures of spiroplasmas contained non-helical cells which were often branched (Cole et al., 1973). Possibly the morphology of different strains may change if their environment changes and indeed we have observed that some batches of horse serum cause changes in the cell and colony morphology of spiroplasmas. However, the absence of helical organisms in strain ASP-I cultures under any of the conditions imposed, indicated that this strain was a nonhelical variant of $S$. citri.

Despite its different morphology strain ASP-I grew as well as strain SP-A. The apparent delayed start of exponential growth, as measured by c.f.u., may have been caused by the 
clumping tendency of the non-helical organisms. Acholeplasma laidlawii infected with a virus produces atypical cratered colonies whereas when uninfected, it gives typical 'fried egg' colonies (Milne, Thompson \& Taylor-Robinson, 1972). However, it seems unlikely that the smooth colonies produced by strain ASP-I reflected the absence of viruses, since this strain contained all three spiroplasma viruses. The well-defined colony morphology appeared to be due to non-motile filaments being unable to form satellite micro-colonies, in contrast to normal spiroplasma colonies with their poorly defined edges and granular appearance caused by motile organisms moving away from the parent colony.

The absence of a membrane protein band in gel electrophoresis implied that at least one protein which might be of structural importance was either absent or bound less firmly into the membrane of strain ASP-I. Altered morphology and associated loss of motility, however, did not affect pathogenicity.

The variant may have arisen as a result of a single spontaneous mutation during the first two subcultures after primary isolation, but we have never observed similar mutations during a great many subcultures of other isolates. A non-helical form of $S$. citri may be present in some diseased trees together with the helical form. If this variant is found to occur in natural infections, it may be necessary to use criteria other than helical morphology for taxonomic purposes.

The authors wish to thank Dr R. M. Cole for examining cultures for the presence of viruses.

\section{REFERENCES}

CLYDE, W. A. (1964). Mycoplasma species identification based upon growth inhibition by specific antisera. Journal of Immunology 92, 958-965.

Cole, R. M., Tully, J. G., Popkin, T. S. \& BovÉ, J. M. (1973). Morphology, ultrastructure, and bacteriophage infection of the helical mycoplasma-like organism (Spiroplasma citri gen. nov., sp. nov.) cultured from 'Stubborn' disease of citrus. Journal of Bacteriology 115, 367-386.

Cole, R. M., Tully, J. G. \& Popkin, T. J. (1974). Virus-like particles in Spiroplasma citri. In Les Mycoplasmes de l'Homme, des Animaux, des Végétaux et des Insectes, INSERM International Congress, pp. 125-1 32. Edited by J. M. Bové and J. F. Duplan. Paris: INSERM.

DANIELS, M. J. ( ( 969). Lipid synthesis in relation to the cell cycle of Bacillus megaterium км and Escherichia coli. Biochemical Journal I15, 697-70I.

Daniels, M. J. \& MEDdins, B. M. (1973). Polyacrylamide gel electrophoresis of mycoplasma proteins in sodium dodecyl sulphate. Journal of General Microbiology 76, 239-242.

Daniels, M. J., Markham, P. G., Meddins, B. M., Plaskitt, A. K., Townsend, R. \& Bar-Joseph, M. (1973). Axenic culture of a plant pathogenic spiroplasma. Nature, London 244, 523-524.

HuLL, R. (1971). Examination of alfalfa mosaic virus protein on polyacrylamide gels. Virology 45, 767-772.

Markham, P. G., Townsend, R., Bar-Joseph, M., Daniels, M. J., Plaskitt, A. \& Meddins, B. M. (1974). Spiroplasmas are the causal agent of citrus little-leaf disease. Annals of Applied Biology 75, 49-57.

MARMUR, J. (I96I). A procedure for the isolation of deoxyribonucleic acid from microorganisms. Journal of Molecular Biology 3, 208-218.

Milne, R. G., Thompson, G. W. \& TAYLOR-Robinson, D. (I972). Electron microscope observations on Acholeplasma laidlawii viruses. Archiv für die gesamte Virusforschung 37, 378-385.

Razin, S., Hasin, M., Ne'eman, Z. \& Rottem, S. (1973). Isolation, chemical composition, and ultrastructural features of the cell membrane of the mycoplasma-like organism Spiroplasma citri. Journal of Bacteriology I16, I42I-1435.

Saglio, P., L'Hospital, M., Laflèche, D., Dupont, G., Bové, J. M., Tully, J. G. \& Freundt, E. A. (I973). Spiroplasma citri gen. and sp. n.: a mycoplasma-like organism associated with 'Stubborn' disease of citrus. International Journal of Systematic Bacteriology 23, 191-204.

Saglio, P., Davis, R. E., Dalibart, R., Dupont, G. \& BovÉ, J. M. (1974). Spiroplasma citri: L'espèce type des spiroplasmes. In Les Mycoplasmes de l'Homme, des Animaux, des Végétaux et des Insectes, INSERM International Congress, pp. 27-34. Edited by J. M. Bové and J. F. Duplan. Paris: INSERM.

SCRIBA, M. (1968). Experiments to eliminate mycoplasmas from tissue cultures by means of antibiotics. Zeitschrift für medizinische Mikrobiologie und Immunologie 154, 267-276.

Taylor-Robinson, D., Purcell, R. H., Wong, D. C. \& Chanock, R. M. (ig66). Colour test for the measurement of antibody to certain Mycoplasma species based upon acid production. Journal of Hygiene 64, 91-104. 